medRxiv preprint doi: https://doi.org/10.1101/2020.11.17.20232280; this version posted November 18,2020 . The copyright holder for this preprint (which was not certified by peer review) is the author/funder, who has granted medRxiv a license to display the preprint in

All rights reserved. No reuse allowed without permission.

\title{
Beyond Accuracy: Investigating the Potential Clinical Utility of Predicting Functional Dependency and Severe Disability or Death in Successfully Reperfused Patients using Machine Learning
}

Raphael Meier, PhD, ${ }^{1,2}$ Meret Burri, M Med,,$^{3,}$ Samuel Fischer, M Med, ${ }^{3,{ }^{*}}$ Richard McKinley, PhD, ${ }^{1,2}$ Simon Jung, MD, ${ }^{3}$ Thomas Meinel, MD, ${ }^{3}$ Urs Fischer, MD, ${ }^{3}$ Eike I. Piechowiak, MD, ${ }^{1}$ Pasquale Mordasini, MD, ${ }^{1}$ Jan Gralla, MD, ${ }^{1}$ Roland Wiest, MD, ${ }^{1,2}$ and Johannes Kaesmacher, MD, ${ }^{1,2,4}$

1 University Institute of Diagnostic and Interventional Neuroradiology, University Hospital Bern, Inselspital, University of Bern, Bern, Switzerland

2 Support Center for Advanced Neuroimaging, University Hospital Bern, Inselspital, University of Bern, Bern, Switzerland

3 Department of Neurology, University Hospital Bern, Inselspital, University of Bern, Bern, Switzerland

4 Department of Diagnostic, Paediatric and Interventional Radiology, University Hospital Bern, Inselspital, University of Bern, Bern, Switzerland

Corresponding author's name and complete mailing address:

Raphael Meier, PhD

Email: raphael.meier@insel.ch

University Institute of Diagnostic and Interventional Neuroradiology, University Hospital Inselspital, Freiburgstrasse 4, 3010 Bern, Switzerland

or

Johannes Kaesmacher, MD

Email: johannes.kaesmacher@insel.ch

Department of Diagnostic, Paediatric and Interventional Radiology, University Hospital Inselspital, Freiburgstrasse 4, 3010 Bern, Switzerland

* authors share equal contribution

NOTE: This preprint reports new research that has not been certified by peer review and should not be used to guide clinical practice. 
medRxiv preprint doi: https://doi.org/10.1101/2020.11.17.20232280; this version posted November $18,2020$. The copyright holder for this preprint (which was not certified by peer review) is the author/funder, who has granted medRxiv a license to display the preprint in All rights reserved. No reuse allowed without permission.

Keywords: Machine learning, modified Rankin Scale, functional impairment, clinical utility, acute ischemic stroke, deep learning. 
medRxiv preprint doi: https://doi.org/10.1101/2020.11.17.20232280; this version posted November 18,2020 . The copyright holder for this preprint (which was not certified by peer review) is the author/funder, who has granted medRxiv a license to display the preprint in

All rights reserved. No reuse allowed without permission.

\section{Abstract}

Objectives: Machine learning (ML) has been demonstrated to improve the prediction of functional outcome in patients with acute ischemic stroke. However, its value in a specific clinical use case has not been investigated. Aim of this study was to assess the clinical utility of $\mathrm{ML}$ models with respect to predicting functional impairment and severe disability or death considering its potential value as a decision-support tool in an acute stroke workflow.

Materials and Methods: Patients $(n=1317)$ from a retrospective, non-randomized observational registry treated with Mechanical Thrombectomy (MT) were included. The final dataset of patients who underwent successful recanalization $(\mathrm{TICI} \geq 2 \mathrm{~b})(\mathrm{n}=932)$ was split in order to develop ML-based prediction models using data of $(n=745,80 \%)$ patients. Subsequently, the models were tested on the remaining patient data $(n=187,20 \%)$. For comparison, baseline algorithms using majority class prediction, SPAN-100 score, PRE score, and Stroke-TPI score were implemented. The ML methods included eight different algorithms (e.g. Support Vector Machines and Random forests), stacked ensemble method and tabular neural networks. Prediction of modified Rankin Scale (mRS) 3-6 (primary analysis) and mRS 5-6 (secondary analysis) at 3 months was performed using 25 baseline variables available at patient admission. ML models were assessed with respect to their ability for discrimination, calibration and clinical utility (decision curve analysis).

Results: Analyzed patients ( $\mathrm{n}=932$ ) showed a median age of 74.7 (IQR 62.7-82.4) years with $(n=461,49.5 \%$ ) being female. ML methods performed better than clinical scores with stacked ensemble method providing the best overall performance including an F1-score of $0.75 \pm 0.01$, an ROC-AUC of $0.81 \pm 0.00$, AP score of $0.81 \pm 0.01$, MCC of $0.48 \pm 0.02$, and ECE of $0.06 \pm$ 0.01 for prediction of $\mathrm{mRS} 3-6$, and an F1-score of $0.57 \pm 0.02$, an ROC-AUC of $0.79 \pm 0.01$, AP score of $0.54 \pm 0.02$, MCC of $0.39 \pm 0.03$, and ECE of $0.19 \pm 0.01$ for prediction of mRS 56. Decision curve analyses suggested highest mean net benefit of $0.09 \pm 0.02$ at a-priori defined threshold (0.8) for the stacked ensemble method in primary analysis (mRS 3-6). Across all methods, higher mean net benefits were achieved for optimized probability thresholds but with considerably reduced certainty (threshold probabilities $0.24-0.47$ ). For the secondary analysis (mRS 5-6), none of the ML models achieved a positive net benefit for the a-priori threshold probability 0.8 .

Conclusions: The clinical utility of ML prediction models in a decision-support scenario aimed at yielding a high certainty for prediction of functional dependency (mRS 3-6) is marginal and not evident for the prediction of severe disability or death (mRS 5-6). Hence, using those models for patient exclusion cannot be recommended and future research should evaluate utility gains after incorporating more advanced imaging parameters. 
medRxiv preprint doi: https://doi.org/10.1101/2020.11.17.20232280; this version posted November 18, 2020. The copyright holder for this preprint (which was not certified by peer review) is the author/funder, who has granted medRxiv a license to display the preprint in All rights reserved. No reuse allowed without permission. 
medRxiv preprint doi: https://doi.org/10.1101/2020.11.17.20232280; this version posted November 18,2020 . The copyright holder for this preprint (which was not certified by peer review) is the author/funder, who has granted medRxiv a license to display the preprint in

All rights reserved. No reuse allowed without permission.

\section{Introduction}

The HERMES data and recent late-time window thrombectomy studies suggested a low number needed to treat with mechanical thrombectomy for improving the functional status of patients with an acute ischemic stroke due to a large vessel occlusion (NNT=2.6 in HERMES) ${ }^{1}$. The inclusion criteria of trials included in the HERMES meta-analysis were relatively strict. However, the large effect sizes observed, promising results derived from observational data in borderline indication groups ${ }^{2-4}$, and a relatively low procedural complication risk $^{1,5,6}$, have been put forward as a major argument widening the indication criteria for mechanical thrombectomy (MT). This is also reflected by statements from the recent ESO/ESMINT guidelines for borderline indications group, suggesting that MT may be reasonable in patients with e.g. low ASPECTS or low NIHSS scores, if inclusion into randomized trials is not possible?

Correspondingly, there was a considerable shift from carefully selecting patients to receive MT (rule in) towards treating the vast majority of patients, except for cases with convincing reasons to withhold MT (rule out). Such a paradigm shifts makes the treatment available for more patients ${ }^{8-10}$, but also inevitably comes with the risk of increasing futile interventions without a clinical benefit ${ }^{11-13}$. If one would be able to precisely determine which patient has a poor outcome despite a technically successful treatment, this can be used to assess the cost-benefit relationship of the treatment and enhance patient-oriented informed decision (e.g. withholding treatment in a patient with legally binding declaration of not wanting to live in moderate or severe dependency).

In the past, many different prediction approaches based on clinical variables at baseline have been introduced in patients with acute ischemic stroke, e.g. simple clinical scores such as the Pittsburgh Response to Endovascular (PRE) therapy score ${ }^{14}$, the Stroke-Thrombolytic Predictive Instrument (Stroke-TPI) ${ }^{15}$, and more recently prediction models based on Machine Learning ${ }^{16,17}$. Machine Learning ( $\mathrm{ML}$ ) methods showed potential to improve prediction performance when compared to clinical scores ${ }^{18}$. However, a recent systematic review ${ }^{19}$ has pointed out the following weaknesses of ML studies conducted so far: Small cohorts (median sample size is 475), no or only simple data imputation (e.g. median imputation), insufficient reporting of hyperparameter tuning, and a strong focus on discrimination with only three studies discussing calibration and no studies discussing clinical utility in context of a possible scenariobased integration into acute stroke care ${ }^{20}$.

Consequently, we set out to evaluate the performance of a wide variety of Machine Learning algorithms (including logistic regression, Support Vector Machines, Random forests) and tabular neural networks for predicting functional dependency and severe disability or death in 
medRxiv preprint doi: https://doi.org/10.1101/2020.11.17.20232280; this version posted November $18,2020$. The copyright holder for this preprint (which was not certified by peer review) is the author/funder, who has granted medRxiv a license to display the preprint in

All rights reserved. No reuse allowed without permission.

patients with successful reperfusion. A particular aim of this study was the assessment of ML models with respect to their clinical utility (i.e. excluding patients from MT based on high likelihood for futile reperfusion) in pre-interventional prediction of 3-months functional impairment.

\section{Methods}

\section{$\underline{\text { Study Design }}$}

We included patients $(n=1317)$ of a single center from a retrospective, non-randomized observational registry purposed to investigate the safety and efficacy of second-generation market-released device for mechanical thrombectomy ${ }^{1}$. Details on the inclusion criteria of the registry were published previously ${ }^{21}$. We excluded patients with age below 18 years $(n=4)$, patients with invalid values in clinical variables $(n=2)$, patients who did not exhibit a proximal large vessel occlusion $(n=121)$, patients with missing TICI score $(n=1)$ and missing 3-months mRS $(n=71)$. Furthermore, analysis was restricted to patients who were successfully recanalized (i.e. patients with $\mathrm{TICl}<2 \mathrm{~b}$ were excluded; $\mathrm{n}=186$ ). Therefore, the developed models are purposed to predict 3-month functional impairment at baseline under the assumption of successful recanalization $(\mathrm{TICl} \geq 2 \mathrm{~b}$ ). Figure 2 provides an overview on the intended use of the ML prediction in an acute stroke workflow. Approval by local ethics committee is available (Bernese/Swiss Stroke Registry: Kantonale Ethikkommission für die Forschung Bern, Bern, Switzerland, amendment access number: 231/2014 and BEYONDSWIFT registry, access number: 2018-00766).

The final dataset $(n=932)$ was split randomly into a training set $(80 \%, n=745)$ used for model development and an internal test set $(20 \%, n=187)$. The flow chart describing patient inclusion and study design is shown in Figure 1.

\footnotetext{
${ }^{1}$ For more details, see https://clinicaltrials.gov/ct2/show/NCT03496064.
} 
medRxiv preprint doi: https://doi.org/10.1101/2020.11.17.20232280; this version posted November 18, 2020. The copyright holder for this preprint (which was not certified by peer review) is the author/funder, who has granted medRxiv a license to display the preprint in perpetuity.

All rights reserved. No reuse allowed without permission.

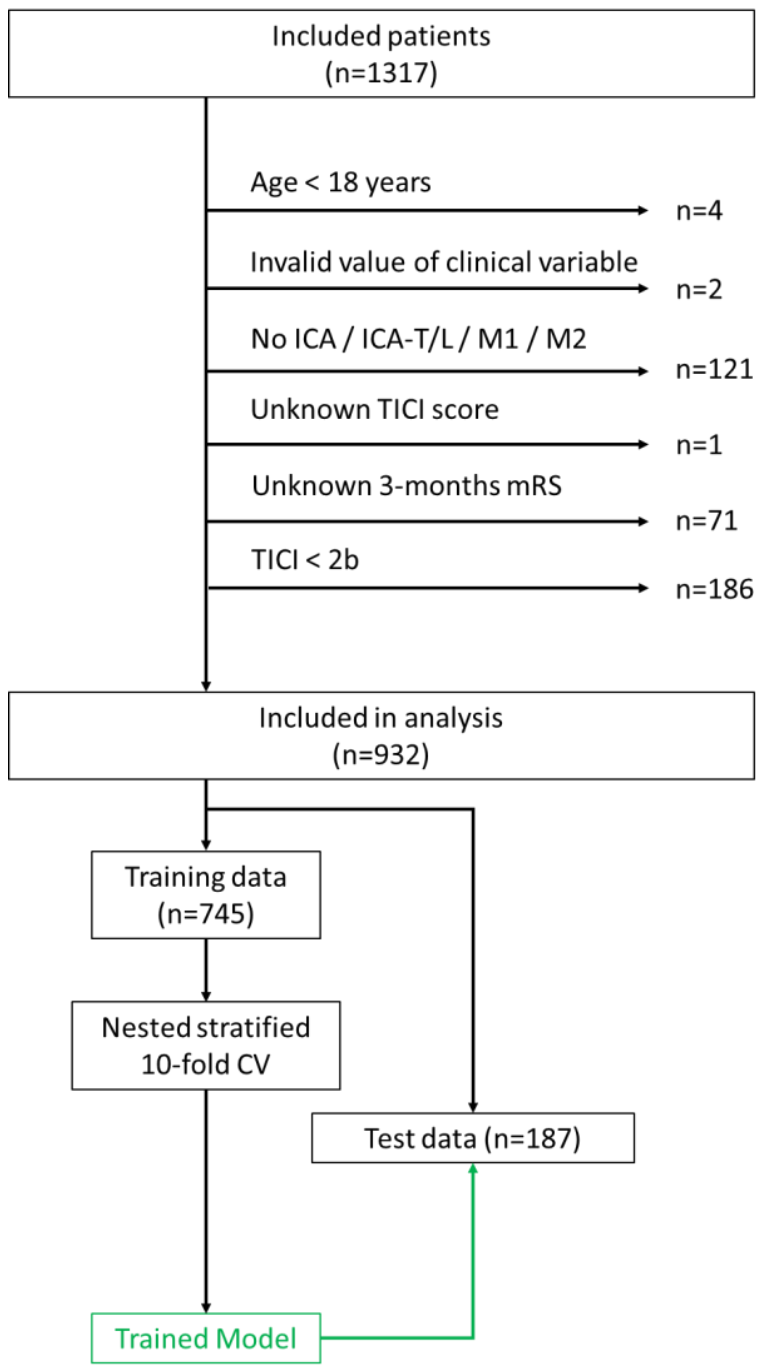

Figure 1. Flow chart of patient inclusion and experimental study design. Model development was based on nested stratified 10-fold cross-validation (CV) using training data $(N=745)$. Trained models were evaluated on separate test set $(n=187)$.

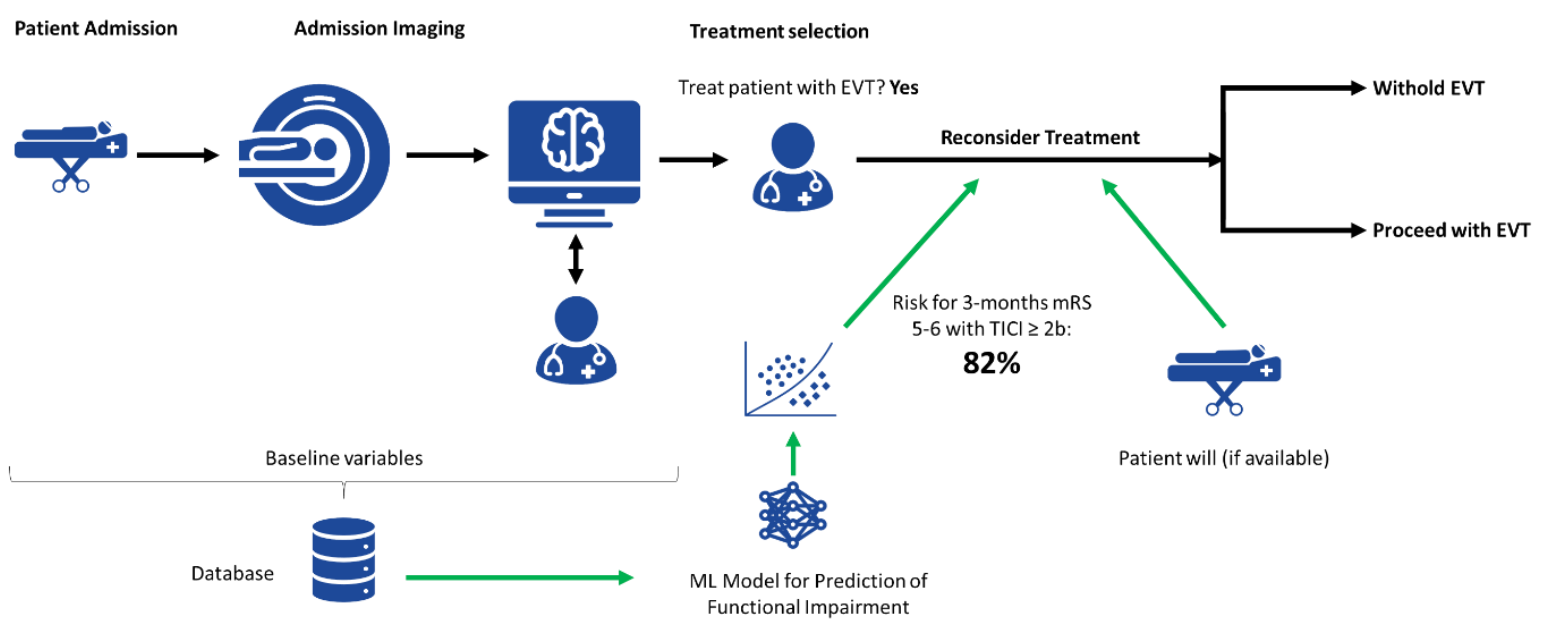

Figure 2. Intended use of ML prediction in a stroke workflow. The ML model outputs a probability (risk score) for mRS 5-6 based on variables available ahead of intervention. This information is provided to the treating physicians after selection of patient for EVT (indicated with green arrows) and could serve as a marker for futile recanalization.

\section{Baseline Variables}


medRxiv preprint doi: https://doi.org/10.1101/2020.11.17.20232280; this version posted November 18,2020 . The copyright holder for this preprint (which was not certified by peer review) is the author/funder, who has granted medRxiv a license to display the preprint in All rights reserved. No perpetuity.

An initial set of 30 variables which are available on admission was included. Input variables (features) were dropped when more than $25 \%$ of the values were missing. Dropped features included risk due to coronary heart disease, systolic \& diastolic blood pressure, admission international normalized ratio (INR), and admission platelet.

Therefore, we considered a total of 25 features available on admission including age on admission (continuous, years), sex (binary), direct vs transfer (binary), pre stroke independence (binary), risk due to diabetes (binary), risk due to arterial hypertension (binary), risk due to dyslipidemia (binary), risk due to smoking (binary), risk due to previous stroke (binary), medication anticoagulation (categorical), medication antiplatelet (categorical), medication statin (binary), admission glucose (continuous, $\mathrm{mmol} / \mathrm{L}$ ), quality symptom onset (categorical), wake up stroke (binary), in hospital stroke (binary), IVT bridging (binary), type of admission imaging (binary), site of occlusion (categorical), ASPECTS (DWI/CT, treated as continuous), tandem occlusion (binary), dissection (binary), NIHSS on admission (treated as continuous), time symptom onset to admission (continuous, min), time admission to groin puncture (continuous, min).

\section{Functional Outcome}

Functional impairment was defined by the modified Rankin Scale (mRS) 3-6 at 3 months. The mRS was dichotomized to serve as binary target variable. The primary analysis included the prediction of mRS 3-6 at 3 months. Despite the fact that such a definition of futile reperfusion is highly debatable, the endpoint was chosen to make the results comparable to reported results from other studies. For the intended use case (Figure 2), a secondary analysis included prediction of mRS 5-6 at 3 months. This secondary endpoint more closely reflects true futile reperfusion, because quality of life may be substantial for patients with $\mathrm{mRS}$ grades 3 and $4^{22}$, while five-year quality-adjusted-life-expectancy in stroke survivors with mRS 5 is overall low $(0.06)^{22-24}$.

Therefore, prediction of 3-months functional impairment based on clinical variables available at baseline was regarded as a binary classification problem ( $m R S \leq 2$ vs. $m R S>2$ and $m R S$ $<5$ vs. $m R S \geq 5$, respectively). The classes in the primary analysis ( $m R S \leq 2$ vs. $m R S>2$ ) were roughly balanced $(n=480,51.5 \% m R S>2)$, whereas classes in the secondary analysis $(m R S<5$ vs. $m R S \geq 5)$ were imbalanced $(n=245,26.3 \% m R S \geq 5)$.

\section{Machine Learning Methods}

Missing values for input features were imputed using k-Nearest Neighbor ( $k-N N)$ imputer with $k=15$ neighbors on normalized feature data of the training and testing data separately. Categorical variables were one-hot encoded for all ML methods except the tabular neural 
medRxiv preprint doi: https://doi.org/10.1101/2020.11.17.20232280; this version posted November 18,2020 . The copyright holder for this preprint (which was not certified by peer review) is the author/funder, who has granted medRxiv a license to display the preprint in

All rights reserved. No reuse allowed without permission.

network which relied on categorical embeddings. Feature values were normalized to $[0,1]$ interval using min-max normalization.

Four baseline algorithms including Majority classifier, SPAN-100 score ${ }^{25}$ (age on admission + NIHSS on admission), PRE score ${ }^{14}$ (function of age on admission, NIHSS on admission and ASPECTS) and Stroke-TPI score ${ }^{15}$ were implemented. Stroke-TPI corresponds to a logistic regression on age on admission, NIHSS on admission, ASPECTS, and admission glucose.

Eight baseline ML algorithms including k-NN classifier using Manhattan distance, linear softmargin SVM based on liblinear, linear soft-margin SVM based on libsvm, non-linear SVM with Radial Basis Function (RBF) kernel, regularized logistic regression with interaction terms, Gradient Boosting (XGBoost classifer), random forest (RF), and Multi-layer Perceptron (MLP) were implemented using Python's (3.7.7) scikit learn ${ }^{26}(0.22 .1)$, xgboost $^{27}$ (1.2.0, for XGBoost classifier), and imbalanced-learn ${ }^{28}$ (0.6.2, for random forest) modules. Class imbalance was tackled using class weights for models in scikit learn and majority class undersampling of each bootstrap sample for the random forest. Calibration of the SVM models was improved using Platt's scaling ${ }^{29}$.

The input features included both continuous and categorical (binary) variables. Therefore, we propose an ensemble method which includes a dedicated ML algorithm for each type of variable. In particular, a linear soft-margin SVM is used to process continuous variables only, a Boolean soft-margin SVM using a Tanimoto kernel function ${ }^{30}$ is employed to process the one-hot encoded categorical variables and a random forest is used to operate on all variables. The rationale is that by treating continuous variables and categorical variables separately, we obtain feature spaces with less distorted geometries and thus may potentially improve discrimination between classes for SVMs. The role of the RF is to capture non-linear relationships between features and target variable as well as interactions between input features. The three models (linear SVM, Boolean SVM, and RF) are combined in an ensemble by stacking their probabilistic outputs using a logistic regression model with I2-regularization (to prevent one model from dominating the final decision). Class imbalance was tackled using class weights on the level of the individual models and the stacking method.

Finally, we implemented a tabular neural network based on fast.ai's tabular learner using categorical embeddings ${ }^{31}$. The architecture of the neural network is presented in the Supplementary Materials (Section Hyperparameter Optimization). The loss function was cross entropy with label smoothing to improve the calibration of the final model ${ }^{32}$. Class weights were used in the loss function computation to tackle class imbalance. The model was trained for 80 epochs using Ranger optimizer ${ }^{33}$ with a learning rate of $4 \mathrm{e}-03$ (based on learning rate finder) 
medRxiv preprint doi: https://doi.org/10.1101/2020.11.17.20232280; this version posted November 18,2020 . The copyright holder for this preprint (which was not certified by peer review) is the author/funder, who has granted medRxiv a license to display the preprint in

All rights reserved. No reuse allowed without permission.

and flat cosine annealing ${ }^{34}$. Early stopping ${ }^{35}$ based on the f1-score in the validation set was employed to prevent overfitting.

\section{Machine Learning Model Development \& Testing}

We used a nested, stratified 10-fold cross-validation strategy for model development. In the outer CV loop, the training dataset was split into 10 equally sized subsets. Nine out of the ten subsets were used for training and one for testing. In the inner loop, hyperparameter optimization was performed based on maximization of f1-score in a 10-fold randomized gridsearch using the data of the previously formed nine folds. A detailed overview on the hyperparameters of the ML algorithms is shown in the Supplementary Table 1.

For model testing, we trained ML algorithms using the setting of the nested CV's inner loop on the complete training data (10-fold randomized grid search) and applied the resulting ML model to separate test data $(n=187)$. We repeated this process 20 times using a different random seed for algorithm initialization in each run. It has been shown that performance of Deep Learning methods varies considerably depending on the choice of random seed ${ }^{36}$, and thus our intention was to capture this aspect.

\section{Statistical analysis}

Univariate associations of clinical variables with functional outcome were assessed using Mann-Whitney U-test for continuous variables and Chi-square test for categorical variables (for primary analysis only). The statistical analysis of the different ML methods investigated model discrimination, calibration and clinical utility. Discrimination refers to the ability of the ML method to separate the two classes. Calibration refers to the ability of the ML model to provide accurate probability estimates. Finally, clinical utility can be regarded as a combination of discrimination and calibration with added clinical context in form of an a-priori defined threshold on predicted risk of functional impairment. In order to assess the ML models ability to discriminate at the threshold of $p=0.5$, we employed accuracy, balanced accuracy, precision, recall, f-1 score, specificity, and Matthew's correlation coefficient (MCC). In addition, the Area Under the Curve (AUC) of the Receiver operating characteristic and the Average Precision (AP) score are reported as measures across all possible thresholds. The calibration of $\mathrm{ML}$ models was quantified using the Brier score and Expected Calibration Error (ECE) based on 10 bins. Feature importance was computed for all methods using the permutation method ${ }^{37}$ on the test set. We defined permutation feature importance through the decrease in f1-score when the values of a single feature are randomly shuffled. Decision curve analysis ${ }^{38}$ was employed to quantify the clinical utility of the ML models on test data. In particular, we defined a-priori a probability threshold of $p=0.8$ for risk of functional impairment (mRS 3-6) and severe disability or death (mRS 5-6) to assess net benefit (=difference between fraction of true positives and 
medRxiv preprint doi: https://doi.org/10.1101/2020.11.17.20232280; this version posted November 18,2020 . The copyright holder for this preprint (which was not certified by peer review) is the author/funder, who has granted medRxiv a license to display the preprint in perpetuity.

All rights reserved. No reuse allowed without permission.

false positives, in which the latter are weighted by odds of probability threshold). In addition, we determined optimal probability thresholds for all models during model development to maximize f1-score. Net benefit for f1-optimized probability thresholds was reported as well. Results are reported as mean \pm 1 standard deviation based on the stratified 10-fold crossvalidation for model development. Performance on test data was reported as mean \pm 1 standard deviation over 20 runs with different random seeds for algorithm initialization.

\section{Results}

\section{Baseline characteristics}

The median age of included patients ( $N=932)$ was 74.7 (62.7-82.4) years with $(n=461,49.5 \%)$ being female. Baseline characteristics of patients in training and test set are shown in Table 1. Univariate associations of clinical variables with functional outcome was assessed for both training and test data. For training data, age on admission, admission glucose, NIHSS on admission, ASPECTS, time symptom onset to admission, pre stroke independence, risk factor diabetes, risk factor arterial hypertension, risk factor smoking, anticoagulation medication, antiplatelet medication, IVT bridging, type of imaging, and site of occlusion were significantly different between patients with $m R S \leq 2$ and patients with $m R S>2(P<0.01)$. For the test data, significant associations of ASPECTS, time symptom onset to admission, risk factor arterial hypertension, risk factor smoking, anticoagulation medication, antiplatelet medication, IVT bridging and site of occlusion were not present. However, time admission to groin puncture was significantly different between patients $m R S \leq 2$ and patients with $m R S>2(P<0.01)$.

Table 1. Baseline characteristics of all included patients (shown for primary analysis). Continuous variables were reported as median and interquartile range (IQR). Categorical variables were reported as counts (proportions).

\begin{tabular}{|c|c|c|c|c|c|c|}
\hline & \multicolumn{3}{|c|}{ Training data $(n=745)$} & \multicolumn{3}{|c|}{ Test data $(n=187)$} \\
\hline & $\begin{array}{l}\mathrm{mRS} \leq 2 \\
(\mathrm{n}=361)\end{array}$ & $\begin{array}{l}\mathrm{mRS}>2 \\
(\mathrm{n}=384)\end{array}$ & P-value & $\begin{array}{l}m R S \leq 2 \\
(n=91)\end{array}$ & $\begin{array}{l}\mathrm{mRS}>2 \\
(\mathrm{n}=96)\end{array}$ & P-value \\
\hline Age on admission & $\begin{array}{l}68.8(57.8- \\
77.4)\end{array}$ & $\begin{array}{l}79.2(68.9- \\
85.4)\end{array}$ & $\mathrm{P}<0.01$ & $\begin{array}{l}72(57.4- \\
77.3)\end{array}$ & $\begin{array}{l}80.8(74.2- \\
85.1)\end{array}$ & $\mathrm{P}<0.01$ \\
\hline Sex, female & $178(49.3 \%)$ & $184(47.9 \%)$ & $\mathrm{P}=0.759$ & $\begin{array}{l}39 \\
(42.9 \%)\end{array}$ & $60(62.5 \%)$ & $\mathrm{P}=0.01$ \\
\hline Admission glucose (mmol/L) & $6.3(5.7-7.2)$ & $7.0(6-8.4)$ & $\mathrm{P}<0.01$ & $\begin{array}{l}6(5.5- \\
7.1)\end{array}$ & $\begin{array}{l}7.3(6.3- \\
8.3)\end{array}$ & $\mathrm{P}<0.01$ \\
\hline NIHSS on admission & $12(8-17)$ & $17(12-21)$ & $P<0.01$ & $14(7-17)$ & $19(12-21)$ & $P<0.01$ \\
\hline ASPECTS (DWI/CT) & $8(7-9)$ & $7(5-9)$ & $\mathrm{P}<0.01$ & $8(7-9)$ & $8(7-9)$ & $\mathrm{P}=0.186$ \\
\hline $\begin{array}{l}\text { Time symptom onset to admission } \\
\text { (min) }\end{array}$ & $122(70-243)$ & $161(85-273)$ & $\mathrm{P}<0.01$ & $\begin{array}{l}124(67- \\
240)\end{array}$ & $\begin{array}{l}159(85- \\
254)\end{array}$ & $\mathrm{P}=0.152$ \\
\hline $\begin{array}{l}\text { Time admission to groin puncture } \\
\text { (min) }\end{array}$ & $87(62-104)$ & $87(65-106)$ & $\mathrm{P}=0.394$ & $\begin{array}{l}91(71- \\
125)\end{array}$ & $\begin{array}{l}83(53- \\
102)\end{array}$ & $\mathrm{P}<0.01$ \\
\hline Transfer from another hospital & $111(30.7 \%)$ & $125(32.6 \%)$ & $\mathrm{P}=0.653$ & $\begin{array}{l}23 \\
(25.3 \%)\end{array}$ & $35(36.5 \%)$ & $\mathrm{P}=0.135$ \\
\hline Pre stroke independence & $350(97 \%)$ & $312(81.2 \%)$ & $P<0.01$ & $\begin{array}{l}88 \\
(96.7 \%)\end{array}$ & $78(81.2 \%)$ & $\mathrm{P}<0.01$ \\
\hline Risk Factor: Diabetes & $38(10.5 \%)$ & $79(20.6 \%)$ & $\mathrm{P}<0.01$ & $7(7.7 \%)$ & $22(22.9 \%)$ & $\mathrm{P}<0.01$ \\
\hline $\begin{array}{l}\text { Risk Factor: Arterial } \\
\text { Hypertension }\end{array}$ & $231(64 \%)$ & $296(77.1 \%)$ & $\mathrm{P}<0.01$ & $\begin{array}{l}58 \\
(63.7 \%)\end{array}$ & $74(77.1 \%)$ & $\mathrm{P}=0.066$ \\
\hline Risk Factor: Dyslipidemia & $208(57.6 \%)$ & $217(56.5 \%)$ & $\mathrm{P}=0.817$ & $\begin{array}{l}57 \\
(62.6 \%) \\
\end{array}$ & $48(50 \%)$ & $\mathrm{P}=0.111$ \\
\hline Risk Factor: Smoking & $123(34.1 \%)$ & $67(17.4 \%)$ & $P<0.01$ & $\begin{array}{l}23 \\
(25.3 \%)\end{array}$ & $14(14.6 \%)$ & $\mathrm{P}=0.099$ \\
\hline Risk Factor: Previous CVI & $36(10 \%)$ & $53(13.8 \%)$ & $\mathrm{P}=0.134$ & $9(9.9 \%)$ & $14(14.6 \%)$ & $\mathrm{P}=0.451$ \\
\hline
\end{tabular}


medRxiv preprint doi: https://doi.org/10.1101/2020.11.17.20232280; this version posted November 18,2020 . The copyright holder for this preprint (which was not certified by peer review) is the author/funder, who has granted medRxiv a license to display the preprint in perpetuity.

All rights reserved. No reuse allowed without permission.

\begin{tabular}{|c|c|c|c|c|c|c|}
\hline Statin & $99(27.4 \%)$ & $121(31.5 \%)$ & $\mathrm{P}=0.254$ & $\begin{array}{l}22 \\
(24.2 \%\end{array}$ & $20(20.8 \%)$ & $\mathrm{P}=0.71$ \\
\hline $\begin{array}{rc}\text { Anticoagulation } \\
-\quad \text { None } \\
-\quad \text { VKA } \\
-\quad \text { NOAC }\end{array}$ & $\begin{array}{l}316(87.5 \%) \\
27(7.5 \%) \\
18(5 \%)\end{array}$ & $\begin{array}{l}301(78.4 \%) \\
48(12.5 \%) \\
35(9.1 \%)\end{array}$ & $\mathrm{P}<0.01$ & $\begin{array}{l}84 \\
(92.3 \%) \\
3(3.3 \%) \\
4(4.4 \%)\end{array}$ & $\begin{array}{l}78(81.3 \%) \\
12(12.5 \%) \\
6(6.3 \%)\end{array}$ & $\mathrm{P}=0.053$ \\
\hline $\begin{aligned} \text { Antiplatelet } \\
-\quad \text { None } \\
-\quad \text { Mono } \\
-\quad \text { Double }\end{aligned}$ & $\begin{array}{l}256(71 \%) \\
94(26 \%) \\
11(3 \%)\end{array}$ & $\begin{array}{l}240(62.5 \%) \\
137(35.7 \%) \\
7(1.8 \%)\end{array}$ & $\mathrm{P}<0.01$ & $\begin{array}{l}63 \\
(69.2 \%) \\
27 \\
(29.7 \%) \\
1(1.1 \%)\end{array}$ & $\begin{array}{l}62(64.6 \%) \\
34(35.4 \%) \\
0(0 \%)\end{array}$ & $\mathrm{P}=0.432$ \\
\hline IVT Bridging & $168(46.5 \%)$ & $137(35.7 \%)$ & $\mathrm{P}<0.01$ & $\begin{array}{l}42 \\
(46.2 \%)\end{array}$ & $35(36.5 \%)$ & $\mathrm{P}=0.231$ \\
\hline Type of Imaging (CT vs. MRI) & $137(38 \%)$ & $218(56.8 \%)$ & $\mathrm{P}<0.01$ & $\begin{array}{l}26 \\
(28.6 \%)\end{array}$ & $62(64.6 \%)$ & $\mathrm{P}<0.01$ \\
\hline $\begin{aligned} & \text { Site of Occlusion } \\
&- \text { ICA } \\
&- \text { ICA T/L } \\
&- \text { M1 } \\
&- \text { M2 }\end{aligned}$ & $\begin{array}{l}13(3.6 \%) \\
59(16.3 \%) \\
227(62.9 \%) \\
62(17.2 \%)\end{array}$ & $\begin{array}{l}21(5.5 \%) \\
100(26 \%) \\
207(53.9 \%) \\
56(14.6 \%)\end{array}$ & $\mathrm{P}<0.01$ & $\begin{array}{l}3(3.3 \%) \\
19 \\
(20.9 \%) \\
52 \\
(57.1 \%) \\
17 \\
(18.7 \%)\end{array}$ & $\begin{array}{l}2(2 \%) \\
30(31.3 \%) \\
50(52.1 \%) \\
14(14.6 \%)\end{array}$ & $\mathrm{P}=0.413$ \\
\hline Tandem occlusion & $48(13.3 \%)$ & $49(12.8 \%)$ & $\mathrm{P}=0.914$ & $6(6.6 \%)$ & $16(16.7 \%)$ & $\mathrm{P}=0.056$ \\
\hline Dissection & $16(4.4 \%)$ & $13(3.4 \%)$ & $\mathrm{P}=0.583$ & $2(2.2 \%)$ & $1(1 \%)$ & $\mathrm{P}=0.963$ \\
\hline $\begin{array}{cl}\text { Quality of symptom onset } \\
-\quad \text { Noticed } \\
-\quad \text { Last seen well } \\
-\quad \text { Unknown }\end{array}$ & $\begin{array}{l}283(78.4 \%) \\
55(15.2 \%) \\
23(6.4 \%)\end{array}$ & $\begin{array}{l}279(72.7 \%) \\
75(19.5 \%) \\
30(7.8 \%)\end{array}$ & $\mathrm{P}=0.19$ & $\begin{array}{l}70 \\
(37.4 \%) \\
16 \\
(8.6 \%) \\
5(2.7 \%)\end{array}$ & $\begin{array}{l}71(38 \%) \\
17(9.1 \%) \\
8(4.3 \%)\end{array}$ & $\mathrm{P}=0.742$ \\
\hline In hospital stroke & $7(1.9 \%)$ & $12(3.1 \%)$ & $\mathrm{P}=0.427$ & $3(3.3 \%)$ & $4(4.2 \%)$ & $\mathrm{P}=0.942$ \\
\hline Wake up stroke & $43(11.9 \%)$ & $55(14.3 \%)$ & $\mathrm{P}=0.387$ & $\begin{array}{l}14 \\
(15.4 \%)\end{array}$ & $9(9.4 \%)$ & $\mathrm{P}=0.304$ \\
\hline
\end{tabular}

\section{Prediction of Functional Impairment and Severe Disability or Death}

Discrimination of ML methods (except for $\mathrm{k}-\mathrm{NN}$ classifier) for prediction of $\mathrm{mRS} 3-6$ at 3 months was superior when compared to naïve baseline algorithms (majority classifier, SPAN100 score, PRE score, Stroke-TPI score). Performance of all ML methods (except for k-NN classifier) was in a similar range. An overview of the results is provided in Table 2 (full data presented in Supplementary Table 2). Best overall performance on test data was achieved by the stacked ensemble method with F1-score of $0.75 \pm 0.01$, ROC-AUC of $0.81 \pm 0.00$, AP score of $0.81 \pm 0.01$, MCC of 0.48 , and ECE of $0.06 \pm 0.01$. Computation of permutation importance revealed that among all methods (except k-NN classifier) the most important features included age on admission, NIHSS on admission, and pre stroke independence. The feature importance of the stacked ensemble method are shown in Figure 3 (see Supplementary Figures $1 \& 2$ for other methods and for secondary analysis).

When looking at the performance for prediction of mRS 5-6 at 3 months (secondary analysis) a considerable drop in performance for all $M L$ methods can be observed. The stacked ensemble method achieved F1-score of $0.57 \pm 0.02$, ROC-AUC of $0.79 \pm 0.01$, AP score of $0.54 \pm 0.02$, MCC of $0.39 \pm 0.03$, and ECE of $0.19 \pm 0.01$ on the test set. An overview of the results for the secondary analysis can be found in the Supplementary Table 3. 
medRxiv preprint doi: https://doi.org/10.1101/2020.11.17.20232280; this version posted November 18, 2020. The copyright holder for this preprint (which was not certified by peer review) is the author/funder, who has granted medRxiv a license to display the preprint in

All rights reserved. No reuse allowed without permission.

Table 2. Performance for $m R S$ 3-6 prediction. Values are reported as mean \pm std. Brier score and ECE are reported for ML algorithms only. (for results of 10-fold cross-validation on training data, see Supplementary Table 2)

\begin{tabular}{|c|c|c|c|c|c|c|c|c|c|c|c|}
\hline Dataset & Method & Accuracy & Precision & Recall & $\begin{array}{l}\text { F1- } \\
\text { Score }\end{array}$ & Specificity & $\begin{array}{l}\text { ROC- } \\
\text { AUC }\end{array}$ & AP & $\begin{array}{l}\text { Matthews } \\
\text { corr. }\end{array}$ & $\begin{array}{l}\text { Brier } \\
\text { score }\end{array}$ & ECE \\
\hline $\begin{array}{l}\text { Test } \\
\text { data }\end{array}$ & $\begin{array}{l}\text { Majority } \\
\text { Classifier }\end{array}$ & 0.51 & 0.51 & 1.0 & 0.68 & 0.0 & 0.50 & 0.51 & 0.0 & - & - \\
\hline $\begin{array}{l}\text { Test } \\
\text { data }\end{array}$ & $\begin{array}{l}\text { SPAN100 } \\
\text { Score }\end{array}$ & 0.69 & 0.91 & 0.44 & 0.59 & 0.96 & 0.79 & 0.81 & 0.46 & - & - \\
\hline $\begin{array}{l}\text { Test } \\
\text { data }\end{array}$ & PRE Score & 0.57 & 0.68 & 0.31 & 0.43 & 0.85 & 0.73 & 0.72 & 0.19 & - & - \\
\hline $\begin{array}{l}\text { Test } \\
\text { data }\end{array}$ & $\begin{array}{l}\text { Stroke-TPI } \\
\text { Score }\end{array}$ & 0.70 & 0.70 & 0.73 & 0.71 & 0.67 & 0.78 & 0.78 & 0.40 & - & - \\
\hline $\begin{array}{l}\text { Test } \\
\text { data }\end{array}$ & $\begin{array}{l}\text { K-NN } \\
\text { Classifier }\end{array}$ & $\begin{array}{l}0.66 \quad \pm \\
0.01\end{array}$ & $\begin{array}{l}0.67 \\
0.01\end{array}$ & $\begin{array}{l}0.66 \pm \\
0.01\end{array}$ & $\begin{array}{l}0.67 \pm \\
0.01\end{array}$ & $0.65 \pm 0.01$ & $\begin{array}{l}0.72 \\
\pm \\
0.02\end{array}$ & $\begin{array}{l}0.70 \\
\pm \\
0.02\end{array}$ & $\begin{array}{l}0.32 \quad \pm \\
0.01\end{array}$ & $\begin{array}{l}0.22 \\
\pm \\
0.01\end{array}$ & $\begin{array}{l}0.06 \\
\pm \\
0.01\end{array}$ \\
\hline $\begin{array}{l}\text { Test } \\
\text { data }\end{array}$ & $\begin{array}{l}\text { Linear SVM } \\
\text { (liblinear) }\end{array}$ & $\begin{array}{l}0.71 \\
0.02\end{array}$ & $\begin{array}{l}0.69 \\
0.02\end{array}$ & $\begin{array}{l}0.80 \pm \\
0.01\end{array}$ & $\begin{array}{l}0.74 \pm \\
0.02\end{array}$ & $0.63 \pm 0.03$ & $\begin{array}{l}0.80 \\
\pm \\
0.00\end{array}$ & $\begin{array}{l}0.79 \\
\pm \\
0.01\end{array}$ & $\begin{array}{l}0.43 \\
0.04\end{array}$ & $\begin{array}{l}0.19 \\
\pm \\
0.00\end{array}$ & $\begin{array}{l}0.08 \\
\pm \\
0.01\end{array}$ \\
\hline $\begin{array}{l}\text { Test } \\
\text { data }\end{array}$ & $\begin{array}{l}\text { Linear SVM } \\
\text { (libsvm) }\end{array}$ & $\begin{array}{l}0.72 \\
0.02\end{array}$ & $\begin{array}{l}0.70 \\
0.02\end{array}$ & $\begin{array}{l}0.79 \pm \\
0.02\end{array}$ & $\begin{array}{l}0.74 \pm \\
0.02\end{array}$ & $0.64 \pm 0.02$ & $\begin{array}{l}0.80 \\
\pm \\
0.01\end{array}$ & $\begin{array}{l}0.79 \\
\pm \\
0.01\end{array}$ & $\begin{array}{l}0.44 \\
0.03\end{array}$ & $\begin{array}{l}0.18 \\
\pm \\
0.00\end{array}$ & $\begin{array}{l}0.08 \\
\pm \\
0.01\end{array}$ \\
\hline $\begin{array}{l}\text { Test } \\
\text { data }\end{array}$ & $\begin{array}{l}\text { Non-linear } \\
\text { SVM }\end{array}$ & $\begin{array}{l}0.73 \\
0.01\end{array}$ & $\begin{array}{l}0.71 \\
0.01\end{array}$ & $\begin{array}{l}0.80 \pm \\
0.00\end{array}$ & $\begin{array}{l}0.75 \pm \\
0.01\end{array}$ & $0.65 \pm 0.02$ & $\begin{array}{l}0.80 \\
\pm \\
0.01\end{array}$ & $\begin{array}{l}0.80 \\
\pm \\
0.01\end{array}$ & $\begin{array}{l}0.48 \\
0.02\end{array}$ & $\begin{array}{l}0.18 \\
\pm \\
0.00\end{array}$ & $\begin{array}{l}0.09 \\
\pm \\
0.00\end{array}$ \\
\hline $\begin{array}{l}\text { Test } \\
\text { data }\end{array}$ & $\begin{array}{l}\text { Regularized } \\
\text { Logistic } \\
\text { Regression }\end{array}$ & $\begin{array}{l}0.70 \\
0.01\end{array}$ & $\begin{array}{l}0.68 \\
0.01\end{array}$ & $\begin{array}{l}0.79 \pm \\
0.01\end{array}$ & $\begin{array}{l}0.73 \pm \\
0.01\end{array}$ & $0.61 \pm 0.02$ & $\begin{array}{l}0.79 \\
\pm \\
0.00\end{array}$ & $\begin{array}{l}0.79 \\
\pm \\
0.01\end{array}$ & $\begin{array}{l}0.41 \\
0.03\end{array}$ & $\begin{array}{l}0.19 \\
\pm \\
0.00\end{array}$ & $\begin{array}{l}0.10 \\
\pm \\
0.01\end{array}$ \\
\hline $\begin{array}{l}\text { Test } \\
\text { data }\end{array}$ & XGBoost & $\begin{array}{l}0.72 \\
0.01\end{array}$ & $\begin{array}{l}0.70 \\
0.02\end{array}$ & $\begin{array}{l}0.78 \pm \\
0.02\end{array}$ & $\begin{array}{l}0.74 \pm \\
0.01\end{array}$ & $0.65 \pm 0.04$ & $\begin{array}{l}0.80 \\
\pm \\
0.01\end{array}$ & $\begin{array}{l}0.80 \\
\pm \\
0.01\end{array}$ & $\begin{array}{l}0.44 \\
0.03\end{array}$ & $\begin{array}{l}0.19 \\
\pm \\
0.01\end{array}$ & $\begin{array}{l}0.09 \\
\pm \\
0.02\end{array}$ \\
\hline $\begin{array}{l}\text { Test } \\
\text { data }\end{array}$ & $\begin{array}{l}\text { Balanced } \\
\text { RF }\end{array}$ & $\begin{array}{l}0.73 \\
0.01\end{array}$ & $\begin{array}{l}0.70 \\
0.01\end{array}$ & $\begin{array}{l}0.82 \pm \\
0.01\end{array}$ & $\begin{array}{l}0.75 \pm \\
0.01\end{array}$ & $0.63 \pm 0.02$ & $\begin{array}{l}0.81 \\
\pm \\
0.01\end{array}$ & $\begin{array}{l}0.80 \\
\pm \\
0.01\end{array}$ & $\begin{array}{l}0.46 \\
0.02\end{array}$ & $\begin{array}{l}0.19 \\
\pm \\
0.00\end{array}$ & $\begin{array}{l}0.10 \\
\pm \\
0.01\end{array}$ \\
\hline $\begin{array}{l}\text { Test } \\
\text { data }\end{array}$ & MLP & $\begin{array}{l}0.73 \\
0.01\end{array}$ & $\begin{array}{l}0.71 \\
0.02\end{array}$ & $\begin{array}{l}0.78 \pm \\
0.02\end{array}$ & $\begin{array}{l}0.75 \pm \\
0.01\end{array}$ & $0.66 \pm 0.03$ & $\begin{array}{l}0.80 \\
\pm \\
0.01\end{array}$ & $\begin{array}{l}0.81 \\
\pm \\
0.01\end{array}$ & $\begin{array}{l}0.45 \\
0.02\end{array}$ & $\begin{array}{l}0.19 \\
\pm \\
0.01\end{array}$ & $\begin{array}{l}0.09 \\
\pm \\
0.02\end{array}$ \\
\hline $\begin{array}{l}\text { Test } \\
\text { data }\end{array}$ & $\begin{array}{l}\text { Ensemble } \\
\text { (Stacking) }\end{array}$ & $\begin{array}{l}0.74 \\
0.01\end{array}$ & $\begin{array}{l}0.74 \\
0.02\end{array}$ & $\begin{array}{l}0.76 \pm \\
0.02\end{array}$ & $\begin{array}{l}0.75 \pm \\
0.01\end{array}$ & $0.72 \pm 0.02$ & $\begin{array}{l}0.81 \\
\pm \\
0.00\end{array}$ & $\begin{array}{l}0.81 \\
\pm \\
0.01\end{array}$ & $\begin{array}{l}0.48 \quad \pm \\
0.02\end{array}$ & $\begin{array}{l}0.18 \\
\pm \\
0.01\end{array}$ & $\begin{array}{l}0.06 \\
\pm \\
0.01\end{array}$ \\
\hline
\end{tabular}


medRxiv preprint doi: https://doi.org/10.1101/2020.11.17.20232280; this version posted November 18, 2020. The copyright holder for this preprint (which was not certified by peer review) is the author/funder, who has granted medRxiv a license to display the preprint in

All rights reserved. No reuse allowed without permission.

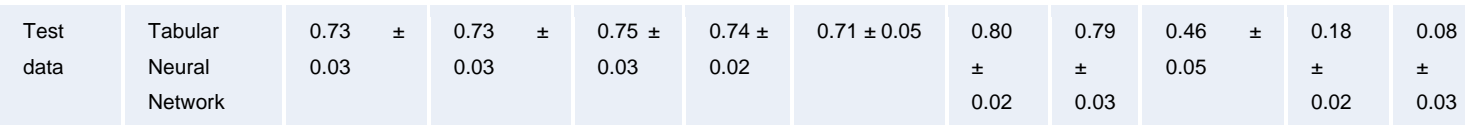

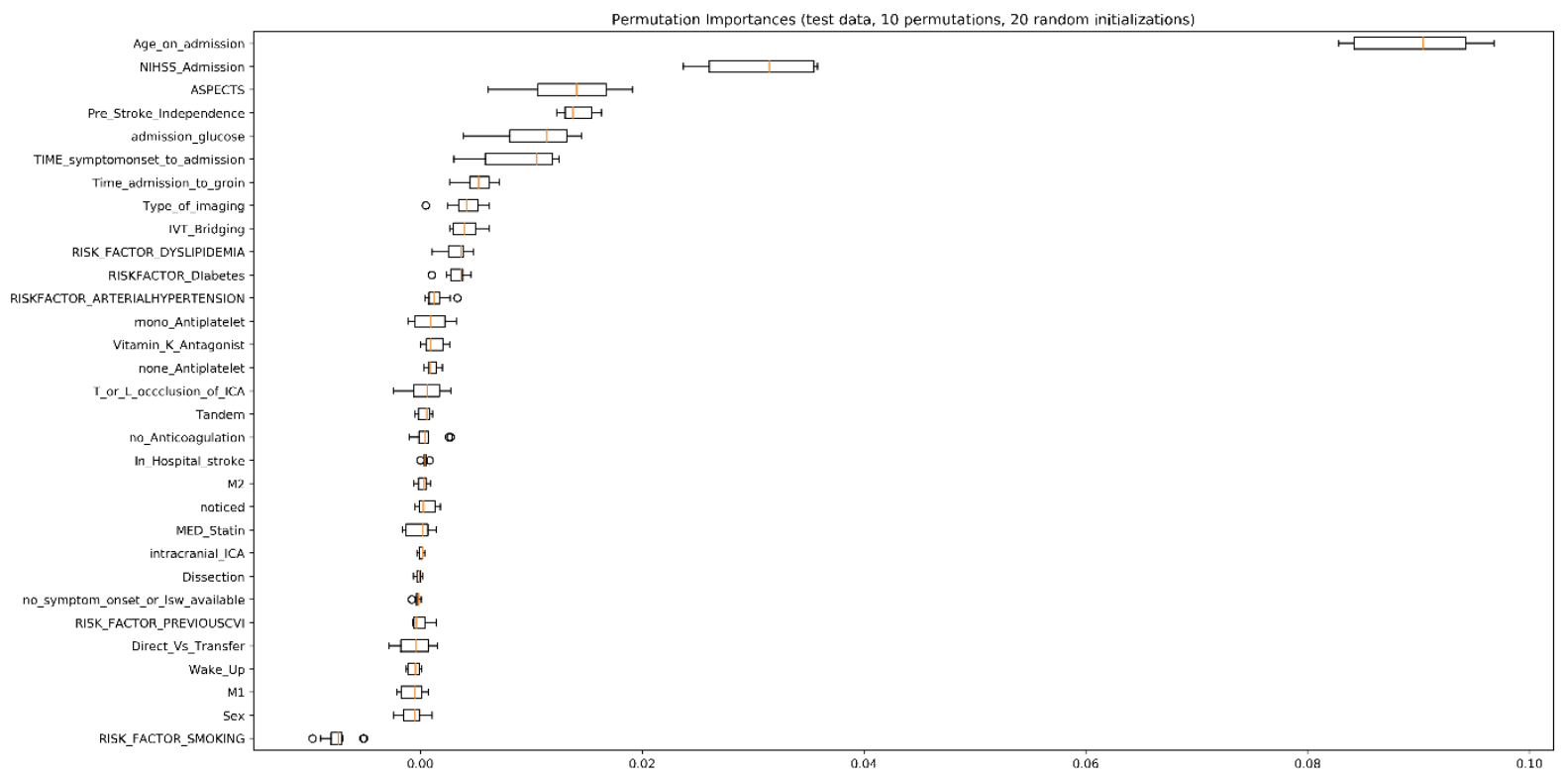

Figure 3. Permutation feature importance computed for the stacked ensemble method (mean values of 10 feature permutations and 20 random initializations).

\section{Clinical Utility of Machine Learning Models}

Decision curve analysis was performed for Stroke-TPI score and all ML methods. It included the mean net benefit for optimized probability thresholds (maximum F1-score) and mean net benefit for a-priori defined probability threshold of $p=0.8$. The results of the primary analysis (mRS 3-6) are shown in Table 3. Exemplary decision curves for regularized logistic regression, stacked ensemble method, and tabular neural network are shown in Figures 4-6 (decision curves of all methods are displayed in the Supplementary Figure 3). Highest mean net benefit of $0.09 \pm 0.02$ for $p=0.8$ was achieved by the stacked ensemble method. Optimized probability thresholds provided higher mean net benefits across all methods but with considerably reduced probability thresholds $(p=0.24-0.47)$. For the secondary analysis (mRS $5-6)$, none of the $\mathrm{ML}$ models achieved a positive net benefit for the threshold $\mathrm{p}=0.8$ (see Supplementary Table 2). Similarly to the primary analysis, the optimized thresholds provided improved mean net benefits for lower probability threshold values $(p=0.22-0.57)$. Detailed results of secondary analysis are provided in the Supplementary Materials (Supplementary Table 4 and Supplementary Figure 4). 
medRxiv preprint doi: https://doi.org/10.1101/2020.11.17.20232280; this version posted November 18,2020 . The copyright holder for this preprint (which was not certified by peer review) is the author/funder, who has granted medRxiv a license to display the preprint in perpetuity.

All rights reserved. No reuse allowed without permission.

Table 3. Results of decision curve analyses for different ML algorithms (and Stroke-TPI score) in case of mRS 36 prediction reported for the f1-optimized probability thresholds and the a-priori defined clinically relevant threshold of $p=0.8$.

\begin{tabular}{|c|c|c|}
\hline Method & $\begin{array}{l}\text { Mean Net Benefit for F1- } \\
\text { optimized threshold }\end{array}$ & Mean Net Benefit for $p=0.8$ \\
\hline Stroke-TPI score & $0.28 \pm 0.00$ for $p=0.40$ & $0.04 \pm 0.00$ \\
\hline k-NN Classifier & $0.36 \pm 0.00$ for $p=0.24$ & $-0.02 \pm 0.03$ \\
\hline Linear SVM (liblinear) & $0.26 \pm 0.01$ for $\mathrm{p}=0.46$ & $0.00 \pm 0.02$ \\
\hline Linear SVM (libsvm) & $0.27 \pm 0.01$ for $p=0.45$ & $0.05 \pm 0.01$ \\
\hline Non-linear SVM & $0.29 \pm 0.00$ for $p=0.38$ & $0.03 \pm 0.02$ \\
\hline $\begin{array}{l}\text { Regularized Logistic } \\
\text { Regression }\end{array}$ & $0.26 \pm 0.01$ for $p=0.45$ & $0.01 \pm 0.02$ \\
\hline XGBoost & $0.30 \pm 0.01$ for $p=0.40$ & $0.06 \pm 0.03$ \\
\hline Balanced Random Forest & $0.26 \pm 0.01$ for $p=0.47$ & $0.06 \pm 0.02$ \\
\hline MLP & $0.31 \pm 0.01$ for $p=0.37$ & $0.01 \pm 0.05$ \\
\hline Ensemble (Stacking) & $0.30 \pm 0.01$ for $p=0.4$ & $0.09 \pm 0.02$ \\
\hline Tabular Neural Network & $0.27 \pm 0.04$ for $p=0.44$ & $0.06 \pm 0.04$ \\
\hline
\end{tabular}

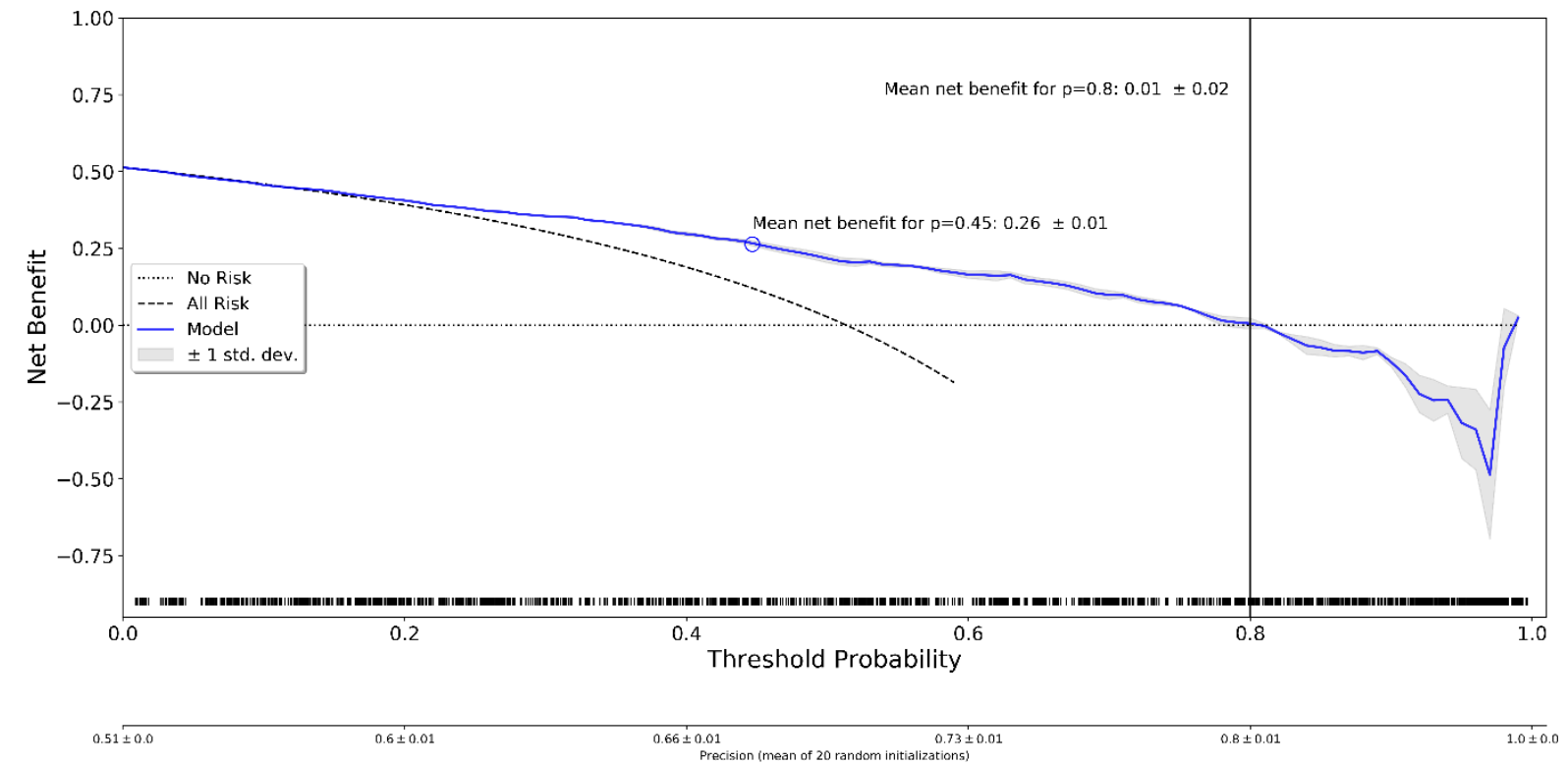

Figure 4. Decision curve analysis for regularized logistic regression. The blue line indicates the mean and the gray shaded region indicates \pm 1 std. band over 20 random initializations. The rug plot shows the samples used for computation of the decision curve. 'No risk' denotes the trivial strategy of always predicting mRS 0-2, and 'All Risk' denotes the strategy of always predicting $\mathrm{mRS}$ 3-6. 
medRxiv preprint doi: https://doi.org/10.1101/2020.11.17.20232280; this version posted November 18, 2020. The copyright holder for this preprint (which was not certified by peer review) is the author/funder, who has granted medRxiv a license to display the preprint in

perpetuity.
All rights reserved. No reuse allowed without permission.

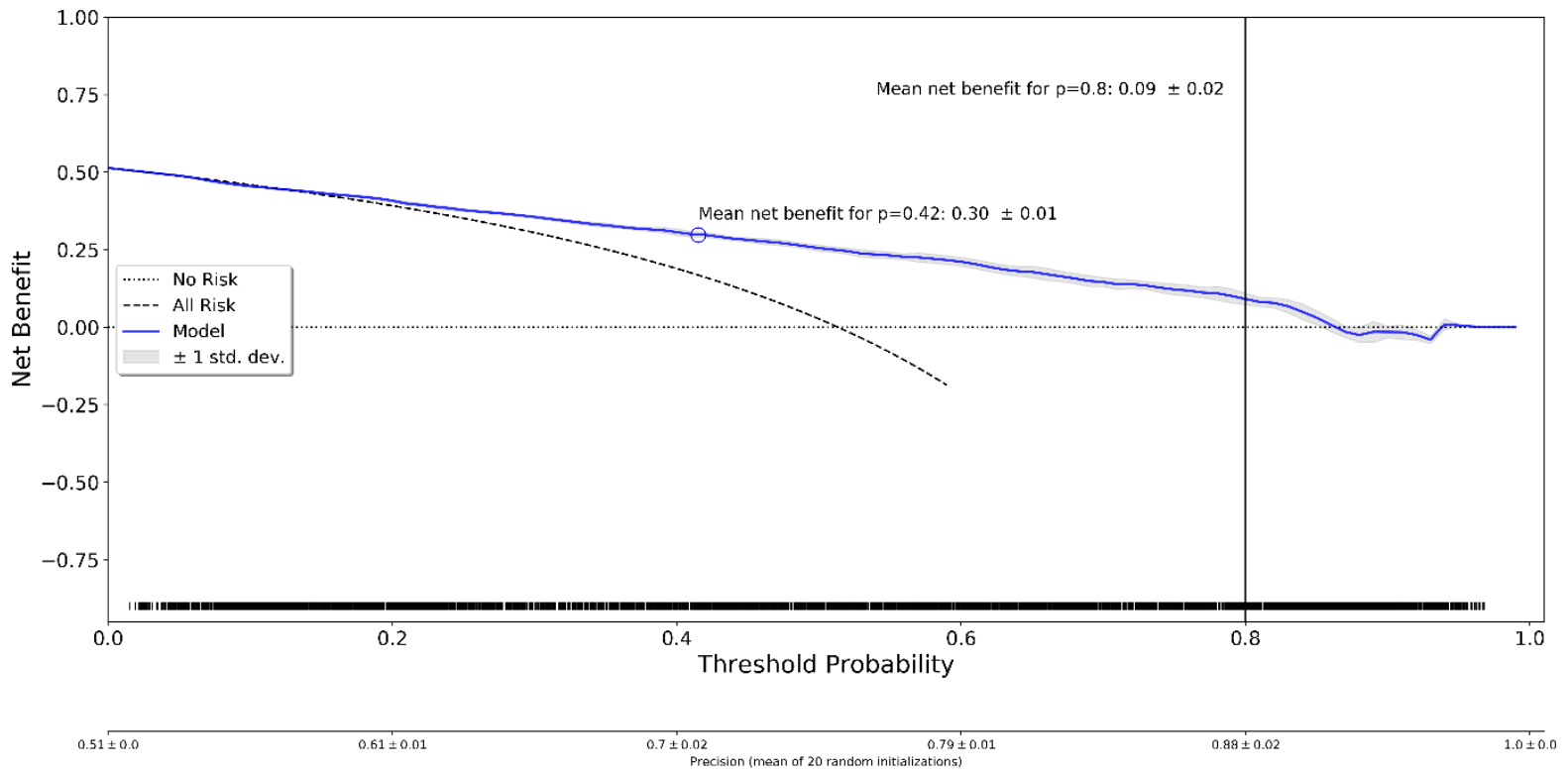

Figure 5. Decision curve analysis for stacked ensemble method. The blue line indicates the mean and the gray shaded region indicates \pm 1 std. band over 20 random initializations. The rug plot shows the samples used for computation of the decision curve. 'No risk' denotes the trivial strategy of always predicting mRS 0-2, and 'All Risk' denotes the strategy of always predicting mRS 3-6.

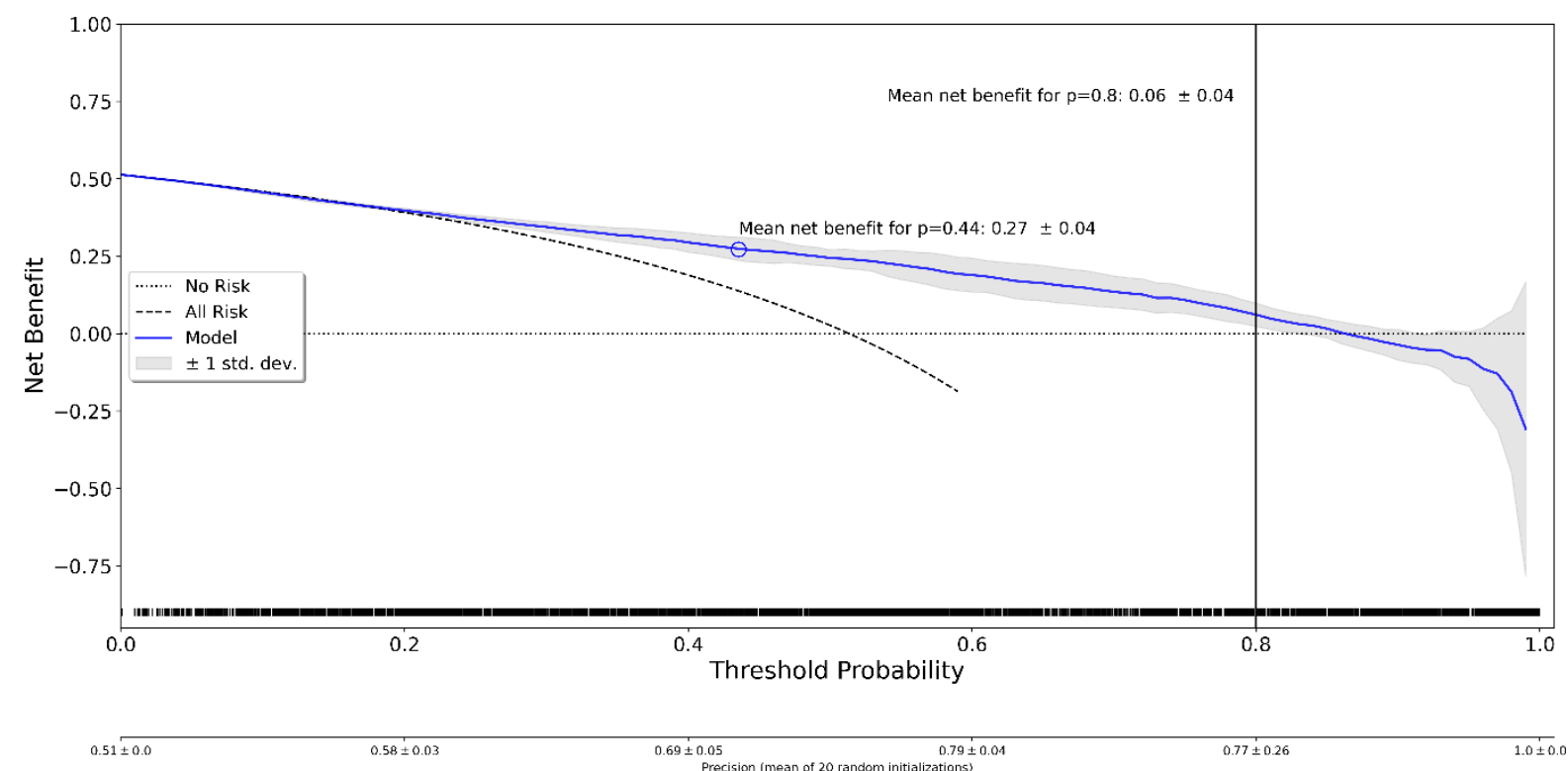

Figure 6. Decision curve analysis for tabular neural network. The blue line indicates the mean and the gray shaded region indicates \pm 1 std. band over 20 random initializations. The rug plot shows the samples used for computation of the decision curve. 'No risk' denotes the trivial strategy of always predicting mRS 0-2, and 'All Risk' denotes the strategy of always predicting mRS 3-6.

\section{Discussion}

While the ability of ML methods to discriminate between good and poor functional outcome looks promising (ROC-AUC $\sim 0.8$ ), clinical utility in a decision-support scenario aimed at 
medRxiv preprint doi: https://doi.org/10.1101/2020.11.17.20232280; this version posted November 18,2020 . The copyright holder for this preprint (which was not certified by peer review) is the author/funder, who has granted medRxiv a license to display the preprint in All rights reserved. No reuse allowed without permission.

yielding high certainty for prediction of functional dependency (mRS 3-6) is marginal and not evident for the prediction of severe disability or death (mRS 5 and 6). In the latter, observed negative net benefits may even indicate potential harm. Net benefit can be improved when using probability thresholds optimized for F1-scores, suggesting that they may have benefits for other clinical scenarios, in which rating of false-positives and false-negative is more balanced (e.g. information gain for patients or next kin).

In our model, we assessed basic variables available at patient admission, which facilitates the transfer of the developed ML methods to other clinical centers. We verified the result by Nishi et al. $^{18}$ that $\mathrm{ML}$ methods can improve prediction of functional outcome when compared to clinical scores. More importantly, we found that most ML methods (with exception of k-NN classifier) provide similar discrimination and calibration performances. Results of primary analysis suggest that the stacked ensemble method performs best with regards to discrimination, calibration and clinical utility. In accordance with previous feature importance analyses reported by Ramos et al. ${ }^{39}$ for ML-based prediction of poor outcome (mRS 5-6) and the analysis by $\mathrm{Xu}$ et $\mathrm{al}^{40}$ on predictors of futile recanalization, we found age on admission, NIHSS on admission, and pre stroke independence to be most predictive. In the secondary analysis, all methods showed a considerable drop in performance when used to predict $\mathrm{mRS}$ 5-6. This may be attributed to lack of information in baseline variables which differentiate patients with mRS 3-4 from mRS 5-6 patients.

In this study, we aimed at filling the lack of evidence regarding studies on clinical utility of $\mathrm{ML}$ models to predict functional outcome in stroke patients. Notably, there is a study available on clinical utility for ML-based outcome prediction in patients with acute ischemic stroke ${ }^{41}$. Jang et al. aimed to compare the clinical utility of $\mathrm{ML}$ and logistic regression models for the prediction of functional outcome in a general population of stroke patients. In contrast, the purpose of our study was to investigate the clinical utility of ML models when integrated in an acute stroke workflow to solve a specific task - the prediction of functional dependency and severe disability or death despite successful recanalization ( $\mathrm{TICl} \geq 2 \mathrm{~b}$ ). The restriction to successfully recanalized patients provided us with a more homogenous patient cohort for model training and provides a potential user with outcome estimates when optimistically assuming that the envisaged intervention is technically successful. Considering a rate of unsuccessful interventions of $15-20 \%^{1,42}$, a decision-support algorithm with a cut-off of $80 \%$ for predicting poor outcome in successfully reperfusion patients would imply that there is a very high overall chance that the intervention is either not successful or futile $(83 \%-84 \%$, depending on the rate of unsuccessful reperfusion). The $80 \%$ cut-off is arbitrary but data on what constitute a sufficiently high certainty for excluding patients from acute stroke reperfusion regimens is not standardized. Certainly, the cut-off needs to be well above $50 \%$ (standard cut-off used for 
medRxiv preprint doi: https://doi.org/10.1101/2020.11.17.20232280; this version posted November 18,2020 . The copyright holder for this preprint (which was not certified by peer review) is the author/funder, who has granted medRxiv a license to display the preprint in

All rights reserved. No reuse allowed without permission.

reporting on discrimination), to ensure that false positive (classifying patients as potential futile reperfusion, despite they gain functional independence or $m R S<5$ ) are weighted more than false negative classifications. Furthermore, our results also show that for more confident cutoffs above $80 \%$ the achieved net benefit is further decreasing even resulting in potential harm (negative net benefit). The exact cut-off deemed useful in a clinical scenario may also depend on other factors including health care resources, cultural perception and available information on the patients good will. In summary, the appealing ROC-AUC reported here and by others ${ }^{39,43}$, should thus be handled cautiously with regards to the clinical utility in excluding patients from reperfusion therapies.

We computed a variety of evaluation metrics to provide a detailed description of the ML methods' performances. In literature, the most frequently reported metric for binary classification problems is the AUC of the ROC curve. However, the ROC-AUC alone can be misleading in case of large class imbalances (i.e. in presence of majority of negative examples). This is also evident in our secondary analysis in which most of the methods achieved similarly good ROC-AUC values as in primary analysis $(\sim 0.8)$ but exhibited a considerably reduced net benefit across all probability thresholds. In addition, the AUC is usually computed over the whole ROC curve taking into account regions which may never be used in practice ${ }^{44}$, whereas the decision curve analysis must be interpreted with respect to clinically relevant thresholds.

The intended use of our ML models is clearly limited to patients selected for treatment with EVT. It is possible that prediction of functional impairment in a more diverse population of patients, which particularly includes individuals not selected for treatment with EVT, may be improved. Nevertheless, the identification of futile recanalization ahead of treatment is of great importance ${ }^{11}$ and we think that our proposed methodology (Figure 2) may serve as a starting point.

In the future, prediction of functional impairment based on patient data available on admission may be improved by incorporation of more elaborate information from laboratory analysis ${ }^{45,46}$ and admission imaging within ML models. The only imaging parameter considered in our feature set was ASPECTS. Several imaging biomarkers have proven to be independently associated with 3-months functional outcome including brain regions affected by the acute lesion $^{47}$, growth of ischemic lesion volume between baseline and 24-hours $\mathrm{CT}^{48}$, final infarct volume (based on follow-up CT, 18-36 hours), brain volume ${ }^{49}$, and white matter hyperintensity volume (based on MRI) ${ }^{50}$. In particular, lesion outcome volumes could be predicted ahead of intervention using dedicated deep learning methods ${ }^{51}$ and be incorporated in our proposed $\mathrm{ML}$ models. 
medRxiv preprint doi: https://doi.org/10.1101/2020.11.17.20232280; this version posted November $18,2020$. The copyright holder for this preprint (which was not certified by peer review) is the author/funder, who has granted medRxiv a license to display the preprint in All rights reserved. No reuse allowed without permission.

In conclusion, the clinical utility of ML methods for prediction of functional dependency and severe disability or death despite successful recanalization is marginal when using baseline variables and when considering a clinical decision-support scenario. Further research should be concentrated on the extraction of more elaborate imaging features from admission imaging and incorporation of such in ML prediction models.

Competing Interests: All authors have completed the ICMJE uniform disclosure form at www.icmje.org/coi disclosure.pdf and declare: no support from any organization for the submitted work; U.F. has received research grants from Medtronic (SWIFT DIRECT and BEYOND SWIFT) and does consultancy for Medtronic, Stryker and CSL Behring outside the submitted work. J.G. has received research grants from Medtronic (SWIFT DIRECT and BEYOND SWIFT) and does consultancy for Medtronic outside the submitted work.

Funding statement: This study was supported by funding received from Swiss National Science Foundation (grant no. 320030L_170060 STRAY-CATS) and the Swiss Heart Foundation (grant no. FF17033 \& FF18059). 
medRxiv preprint doi: https://doi.org/10.1101/2020.11.17.20232280; this version posted November 18,2020 . The copyright holder for this preprint (which was not certified by peer review) is the author/funder, who has granted medRxiv a license to display the preprint in

\section{References}

1. Goyal M, Menon BK, van Zwam WH, Dippel DWJ, Mitchell PJ, Demchuk AM, et al. Endovascular thrombectomy after large-vessel ischaemic stroke: a meta-analysis of individual patient data from five randomised trials. Lancet. 2016;387:1723-1731.

2. Broocks G, Hanning U, Flottmann F, Schönfeld M, Faizy TD, Sporns P, et al. Clinical benefit of thrombectomy in stroke patients with low ASPECTS is mediated by oedema reduction. Brain. 2019;142:1399-1407.

3. Kaesmacher J, Chaloulos-lakovidis P, Panos L, Mordasini P, Michel P, Hajdu SD, et al. Mechanical Thrombectomy in Ischemic Stroke Patients With Alberta Stroke Program Early Computed Tomography Score 0-5. Stroke. 2019;50:880-888.

4. Cagnazzo F, Derraz I, Dargazanli C, Lefevre P-H, Gascou G, Riquelme C, et al. Mechanical thrombectomy in patients with acute ischemic stroke and ASPECTS $\leq 6$ : a meta-analysis. J. Neurointerv. Surg. 2020;12:350-355.

5. Behme D, Gondecki L, Fiethen S, Kowoll A, Mpotsaris A, Weber W. Complications of mechanical thrombectomy for acute ischemic stroke-a retrospective single-center study of 176 consecutive cases. Neuroradiology. 2014;56:467-476.

6. Balami JS, White PM, McMeekin PJ, Ford GA, Buchan AM. Complications of endovascular treatment for acute ischemic stroke: Prevention and management. Int. J. Stroke. 2018;13:348-361.

7. Turc G, Bhogal P, Fischer U, Khatri P, Lobotesis K, Mazighi M, et al. European Stroke Organisation (ESO) - European Society for Minimally Invasive Neurological Therapy (ESMINT) Guidelines on Mechanical Thrombectomy in Acute Ischaemic StrokeEndorsed by Stroke Alliance for Europe (SAFE). Eur. Stroke J. 2019;4:6-12.

8. Alegiani AC, Dorn F, Herzberg M, Wollenweber FA, Kellert L, Siebert E, et al. Systematic evaluation of stroke thrombectomy in clinical practice: The German Stroke Registry Endovascular Treatment. Int. J. Stroke. 2019;14:372-380.

9. Goyal M, Simonsen CZ, Fisher M. Future trials on endovascular stroke treatment: the not-so-easy-to-pluck fruits. Neuroradiology. 2018;60:123-126.

10. Vanacker P, Lambrou D, Eskandari A, Mosimann PJ, Maghraoui A, Michel P. Eligibility and Predictors for Acute Revascularization Procedures in a Stroke Center. Stroke. 2016;47:1844-1849.

11. Chen M. Why futile recanalization matters. J. Neurointerv. Surg. 2020;12:925-926.

12. Pedraza MI, de Lera M, Bos D, Calleja AI, Cortijo E, Gómez-Vicente B, et al. Brain Atrophy and the Risk of Futile Endovascular Reperfusion in Acute Ischemic Stroke. Stroke. 2020;51:1514-1521.

13. Meinel TR, Kaesmacher J, Mosimann PJ, Seiffge D, Jung S, Mordasini P, et al. Association of initial imaging modality and futile recanalization after thrombectomy. Neurology. 2020;10.1212/WNL.0000000000010614.

14. Rangaraju S, Liggins JTP, Aghaebrahim A, Streib C, Sun C-H, Gupta R, et al. Pittsburgh Outcomes After Stroke Thrombectomy Score Predicts Outcomes After Endovascular Therapy for Anterior Circulation Large Vessel Occlusions. Stroke. 2014;45:2298-2304.

15. Kent DM, Ruthazer R, Decker C, Jones PG, Saver JL, Bluhmki E, et al. Development and validation of a simplified Stroke-Thrombolytic Predictive Instrument. Neurology. 
medRxiv preprint doi: https://doi.org/10.1101/2020.11.17.20232280; this version posted November 18,2020 . The copyright holder for this preprint (which was not certified by peer review) is the author/funder, who has granted medRxiv a license to display the preprint in

2015;85:942-949.

16. Van Os HJA, Ramos LA, Hilbert A, Van Leeuwen M, Van Walderveen MAA, Kruyt ND, et al. Predicting outcome of endovascular treatment for acute ischemic stroke: Potential value of machine learning algorithms. Front. Neurol. 2018;9:1-8.

17. Alaka SA, Menon BK, Brobbey A, Williamson T, Goyal M, Demchuk AM, et al. Functional Outcome Prediction in Ischemic Stroke: A Comparison of Machine Learning Algorithms and Regression Models. Front. Neurol. 2020;11:1-9.

18. Nishi H, Oishi N, Ishii A, Ono I, Ogura T, Sunohara T, et al. Predicting Clinical Outcomes of Large Vessel Occlusion before Mechanical Thrombectomy Using Machine Learning. Stroke. 2019;50:2379-2388.

19. Wang W, Kiik M, Peek N, Curcin V, Marshall IJ, Rudd AG, et al. A systematic review of machine learning models for predicting outcomes of stroke with structured data. PLoS One. 2020;15:1-16.

20. Ding L, Liu C, Li Z, Wang Y. Incorporating Artificial Intelligence Into Stroke Care and Research. Stroke. 2020;

21. Kaesmacher J, Maamari B, Meinel TR, Piechowiak El, Mosimann PJ, Mordasini P, et al. Effect of Pre- and In-Hospital Delay on Reperfusion in Acute Ischemic Stroke Mechanical Thrombectomy. Stroke. 2020;51:2934-2942.

22. Rangaraju S, Haussen D, Nogueira RG, Nahab F, Frankel M. Comparison of 3-Month Stroke Disability and Quality of Life across Modified Rankin Scale Categories. Interv. Neurol. 2017;6:36-41.

23. Ganesh A, Luengo-Fernandez R, Pendlebury ST, Rothwell PM. Weights for ordinal analyses of the modified Rankin Scale in stroke trials: A population-based cohort study. EClinicalMedicine. 2020;23:100415.

24. Deb-Chatterji M, Konnopka A, Flottmann F, Leischner H, Fiehler J, Gerloff C, et al. Patient-reported, health-related, quality of life after stroke thrombectomy in clinical practice. Neurology. 2020;95:e1724-e1732.

25. Saposnik G, Guzik AK, Reeves M, Ovbiagele B, Johnston SC. Stroke Prognostication using Age and NIH Stroke Scale: SPAN-100. Neurology. 2013;80:21-28.

26. Pedregosa F, Varoquaux G, Gramfort A, Michel V, Thirion B, Grisel O, et al. Scikitlearn: Machine Learning in Python. J. Mach. Learn. Res. 2011;12.

27. Chen T, Guestrin C. XGBoost: A Scalable Tree Boosting System [Internet]. In: Proceedings of the 22nd ACM SIGKDD International Conference on Knowledge Discovery and Data Mining. New York, NY, USA: ACM; 2016. p. 785-794.

28. Lemaître G, Nogueira F, Aridas CK. Imbalanced-learn: A Python Toolbox to Tackle the Curse of Imbalanced Datasets in Machine Learning. J. Mach. Learn. Res. 2017;18:15.

29. Platt JC. Probabilistic Outputs for Support Vector Machines and Comparisons to Regularized Likelihood Methods. In: ADVANCES IN LARGE MARGIN CLASSIFIERS. MIT Press; 1999. p. 61-74.

30. Ralaivola L, Swamidass SJ, Saigo H, Baldi P. Graph kernels for chemical informatics. Neural Networks. 2005;18:1093-1110.

31. Howard J, Gugger S. fastai: A Layered API for Deep Learning. arXiv. 2020; 
medRxiv preprint doi: https://doi.org/10.1101/2020.11.17.20232280; this version posted November 18,2020 . The copyright holder for this preprint (which was not certified by peer review) is the author/funder, who has granted medRxiv a license to display the preprint in All rights reserved. $\mathrm{No}$

32. Müller R, Kornblith S, Hinton G. When Does Label Smoothing Help? arXiv. 2019;

33. Wright L. Ranger-Deep-Learning-Optimizer [Internet]. Github. 2020;

34. Loshchilov I, Hutter F. SGDR: Stochastic Gradient Descent with Warm Restarts. arXiv. 2016;

35. Prechelt L. Early Stopping - But When? [Internet]. In: Neural Networks: Tricks of the Trade. Lecture Notes in Computer Science. 2012. p. 53-67.

36. Dodge J, Ilharco G, Schwartz R, Farhadi A, Hajishirzi H, Smith N. Fine-Tuning Pretrained Language Models: Weight Initializations, Data Orders, and Early Stopping. arXiv. 2020;

37. Breiman L. Random Forests. Mach. Learn. 2001;

38. Vickers AJ, Elkin EB. Decision Curve Analysis: A Novel Method for Evaluating Prediction Models. Med. Decis. Mak. 2006;26:565-574.

39. Ramos LA, Kappelhof M, Os HJA Van, Chalos V. Predicting Poor Outcome Before Endovascular Treatment in Patients With Acute Ischemic Stroke. 2020;11:1-12.

40. Xu H, Jia B, Huo X, Mo D, Ma N, Gao F, et al. Predictors of Futile Recanalization After Endovascular Treatment in Patients with Acute Ischemic Stroke in a Multicenter Registry Study. J. Stroke Cerebrovasc. Dis. 2020;29:105067.

41. Jang S-K, Chang JY, Lee JS, Lee E-J, Kim Y-H, Han JH, et al. Reliability and Clinical Utility of Machine Learning to Predict Stroke Prognosis: Comparison with Logistic Regression. J. Stroke. 2020;22:403-406.

42. Hill MD, Goyal M, Menon BK, Nogueira RG, McTaggart RA, Demchuk AM, et al. Efficacy and safety of nerinetide for the treatment of acute ischaemic stroke (ESCAPE-NA1): a multicentre, double-blind, randomised controlled trial. Lancet. 2020;395:878-887.

43. Xie Y, Jiang B, Gong E, Li Y, Zhu G, Michel P, et al. JOURNAL CLUB: Use of Gradient Boosting Machine Learning to Predict Patient Outcome in Acute Ischemic Stroke on the Basis of Imaging, Demographic, and Clinical Information. Am. J. Roentgenol. 2019;212:44-51.

44. Brabec J, Machlica L. Bad practices in evaluation methodology relevant to classimbalanced problems. 2018;

45. Yao T, Tian B-L, Li G, Cui Q, Wang C, Zhang Q, et al. Elevated plasma D-dimer levels are associated with short-term poor outcome in patients with acute ischemic stroke: a prospective, observational study. BMC Neurol. 2019;19:175.

46. Bellwald S, Balasubramaniam R, Nagler M, Burri MS, Fischer SDA, Hakim A, et al. Association of anemia and hemoglobin decrease during acute stroke treatment with infarct growth and clinical outcome. PLoS One. 2018;13:e0203535.

47. Haranhalli N, Mbabuike N, Grewal SS, Hasan TF, Heckman MG, Freeman WD, et al. Topographic correlation of infarct area on CT perfusion with functional outcome in acute ischemic stroke. J. Neurosurg. 2020;132:33-41.

48. Bucker A, Boers AM, Bot JCJ, Berkhemer OA, Lingsma HF, Yoo AJ, et al. Associations of Ischemic Lesion Volume With Functional Outcome in Patients With Acute Ischemic Stroke. Stroke. 2017;48:1233-1240.

49. Schirmer MD, Donahue KL, Nardin MJ, Dalca A V., Giese A-K, Etherton MR, et al. 
medRxiv preprint doi: https://doi.org/10.1101/2020.11.17.20232280; this version posted November 18, 2020. The copyright holder for this preprint (which was not certified by peer review) is the author/funder, who has granted medRxiv a license to display the preprint in

All rights reserved. No reuse allowed without permission.

Brain Volume: An Important Determinant of Functional Outcome After Acute Ischemic Stroke. Mayo Clin. Proc. 2020;95:955-965.

50. Ryu W-S, Woo S-H, Schellingerhout D, Jang MU, Park K-J, Hong K-S, et al. Stroke outcomes are worse with larger leukoaraiosis volumes. Brain. 2017;140:158-170.

51. Robben D, Boers AMM, Marquering HA, Langezaal LLCM, Roos YBWEM, van

Oostenbrugge RJ, et al. Prediction of final infarct volume from native CT perfusion and treatment parameters using deep learning. Med. Image Anal. 2020;59:101589. 